\title{
Sistem Pendukung Keputusan Penerimaan Beasiswa PPA Dan BBM Pada Perguruan Tinggi Swasta Provinsi Sumbar, Riau, Jambi Dan Kepri Di Kopertis Wilayah X Padang Menggunakan Metode AHP ( Analytical Hierarchy Process)
}

\author{
Heru Saputra \\ STMIK Indonesia Padang \\ (cooresponding author) h3ru.saputra@gmail.com
}

\begin{abstract}
The process of PPA and BBM's scholarship in Kopertis X Padang still use traditional method in determining of private college that eligible to receive PPA dan BBM scholarship. This process get impact in managing data ineffectively, requiring a a lot of time and frequenting of subjectivity from the scholarship's manager based on the cases a decision supporting system are required to help scholarship's manager in considerating PPA and BBM scholarship selection. In this final project, the decision supporting system is designed by using Analytical Hierarchy Process (AHP) Method. This method will sort of priority the PPA's grantee based on the criteria of the system. Another benefit of this AHP method also provides the best alternative to help scholarship's manager in determining college student who are eligible receving based on their real conditions.
\end{abstract}

Keywords: Systems, Support, Decisions, Analytical, Hierarchy, Process (AHP), Criteria, PPA and BBM's Scholarships

Intisari- Proses seleksi beasiswa PPA dan BBM di Kopertis Wilayah X Padang selama ini masih menggunakan cara manual untuk menentukan Perguruan Tinggi Swast mana yang berhak menerima beasiswa PPA dan BBM sehingga pengelolaan data kurang efektif, membutuhkan waktu yang relatif lama dan sering terjadi subjektifitas dari para pengelola beasiswa. Untuk itu dibutuhkan suatu sistem pendukung keputusan untuk memberikan pertimbangan pihak pengelola beasiswa untuk dalam menyeleksi beasiswa PPA dan BBM. Dalam penelitian ini didesain suatu sistem pendukung keputusan dengan metode Analytical Hierarchy Process (AHP). Sistem pendukung keputusan dengan metode AHP ini akan mengurutkan prioritas penerima beasiswa PPA sesuai dengan kriteria pengambilan keputusan. Sistem pendukung keputusan dengan metode AHP dapat memberikan alternatif terbaik bagi pihak pengelola beasiswa dalam menentukan mahasiswa yang berhak menerima beasiswa sesuai kondisi yang diharapkan.

Kata kunci: Sistem, Pendukung, Keputusan, Analytical, Hierarchy, Process (AHP), Kriteria, Beasiswa PPA dan BBM

\section{PENDAHULUAN}

\section{A. Latar Belakang}

Disetiap lembaga pendidikan khususnya kampus banyak sekali beasiswa yang ditujukan kepada mahasiswa, baik yang berprestasi maupun yang kurang mampu. Beasiswa ditujukan untuk membantu meringankan beban biaya mahasiswa yang mendapatkannya. Untuk memperoleh beasiswa tersebut harus sesuai dengan kriteria yang telah ditetapkan, seperti jumlah penghasilan orang tua, jumlah tanggungan orang tua, jumlah saudara kandung, nilai rata-rata, dan persentase kehadiran mahasiswa yang mana kriteria tersebut itu ditujukan untuk mahasiswa. Beberapa kriteria untuk Perguruan Tinggi Swasta adalah Perguruan Tinggi Swasta aktif, Taat azaz dan akreditasi. Dan untuk membantu menentukan suatu Perguruan Tinggi Swasta menerima beasiswa, maka dapat digunakan sebuah Sistem Pendukung Keputusan (SPK). Sehingga dapat diketahui Perguruan Tinggi Swasta mana yang menerima beasiswa PPA dan BBM.

Sistem Pendukung Keputusan menurut Kusrini pada bukunya yang berjudul "konsep dan aplikasi sistem penunjang keputusan" yang ditulis oleh kusrini (2007:15) mendefinisikan "Sistem penujang keputusan atau Descision Support Sistem (DSS) merupakan sistem informasi interaktif yang menyediakan informasi permodelan, dan pemanipulasian data. Sistem itu untuk membantu pengambilan keputusan dalam situasi yang terstruktur (keputusan yang dilakukan secara berulang-ulang dan secara rutin), situasi yang semistruktur (keputusan yang memilik dua sifat. Sebagian keputusan bisa ditangani oleh komputer dan yang lain tetap harus dilakukan oleh pengambil keputusan), dan situasi yang tidak 
terstruktur (keputusan yang penanganan nya rumit karena tidak terjadi berulang-ulang atau tidak selalu terjadi) dimana tak seorang pun tahu cara pasti bagaimana keputusan dibuat."

Kopertis Wilayah X Padang membutuhkan suatu Sistem Pendukung Keputusan dalam mengambil kebijakan pemberian beasiswa PPA dan BBM pada perguruan tinggi swasta, karena saat ini pihak kopertis mengalami kesulitan dan membutuhkan waktu lama dalam mengambil keputusan tersebut sesuai kriteria penerimaan beasiswa yang telah ditentukan oleh Kopertis Wilayah X Padang. Selain itu pihak kopertis juga membutuhkan sistem ini untuk menghindari ketidak efektifan data dengan menghasilkan laporan data penerima beasiswa dan menjaga keamanan data dalam jangka panjang.

Banyak metode yang digunakan dalam sistem pengambilan keputusan. Salah satu metode tersebut yang digunakan dalam penelitian ini adalah metode Analytical Hierarchy Process (AHP). Konsep metode AHP adalah merubah nilai-nilai kualitatif menjadi nilai kuantitatif. Sehingga keputusan-keputusan yang diambil bisa lebih obyektif. Pada saat ini metode AHP juga telah digunakan oleh beberapa peneliti, misalkan untuk "Penentuan Prioritas Program Kesehatan" [6] atau "Seleksi Mahasiswa Berprestasi [1].

Hasil penelitian ini dapat mempermudah Kopertis Wilayah $\mathrm{X}$ dalam menentukan siapa yang menjadi penerima beasiswa PPA dan BBM. Walaupun demikian, hasil penelitian ini bukan satu-satunya alat yang digunakan untuk pengambilan keputusan, dikarenakan adanya hal-hal yang masih bersifat subyektif. Dan hal ini merupakan hal yang wajar.

\section{B. Rumusan Masalah}

Berdasarkan latar belakang masalah, identifikasi masalah dan batasan masalah maka dapat dirumuskan masalah penelitian yaitu: bagaimana mengambil suatu keputusan dengan Sistem Pendukung Keputusan Penerima beasiswa PPA dan BBM pada Perguruan Tinggi Swasta provinsi Sumbar, Riau , Jambi dan Kepri di Kopertis Wilayah X Padang.

\section{LANDASAN TEORI}

Sistem Penunjang Keputusan (SPK) adalah bagian dari sistem informasi berbasis komputer termasuk sistem berbasis pengetahuan untuk mendukung pengambilan keputusan dalam suatu organisasi atau perusahaan. SPK juga dapat merupakan sistem komputer yang mengolah data menjadi informasi untuk mengambil keputusan dari masalah semiterstruktur yang spesifik. SPK dapat menjadi alat bantu bagi para pengambil keputusan untuk memperluas kapabilitas mereka, namun tidak untuk menggantikan penilaian mereka. SPK ditujukan untuk keputusan-keputusan yang memerlukan penilaian atau pada keputusan-keputusan yang memerlukan penilaian atau pada keputusan-keputusan yang sama sekali tidak dapat didukung oleh algoritma. Menurut Herbert A. Simon proses pengambilan keputusan mempunyai 3 tahap yaitu:

1. Pemahaman

Menyelidiki lingkungan kondisi-kondisi yang memerlukan keputusan data mentah yang diperoleh, diolah dan diperiksa untuk dijadikan petunjuk yang dapat menentukan masalahnya.

2. Perancangan

Menemukan, mengembangkan dan menganalisa arah tindakan yang mungkin dapat dipergunakan. Hal ini mengandung proses-proses untuk memahami masalah, untuk menghasilkan cara pemecahan, dan untuk menguji apakah cara pemecahan tersebut dapat dilaksanakan.

3. Pemilihan

Memilih arah tindakan tertentu dari semua arah tindakan yang ada. Pilihan ditentukan dan dilaksanakan.

Pemerintah melalui Direktorat Jenderal Pendidikan Tinggi Kementerian Pendidikan dan Kebudayaan berupaya mengalokasikan dana untuk memberikan bantuan biaya pendidikan kepada mahasiswa yang orang tuanya tidak mampu untuk membiayai pendidikannya, dan memberikan beasiswa kepada mahasiswa yang mempunyai prestasi tinggi, baik kurikuler maupun ekstrakurikuler. Menurut buku Pedoman Umum Beasiswa Bantuan Biaya Pendidikan Peningkatan Prestasi Akademik Tahun 2015 diperoleh informasi tentang kuota penerima beasiswa PPA dan BBM, yaitu:

1. Kuota calon penerima pada setiap perguruan tinggi negeri dan kopertis ditentukan oleh Direktorat Jenderal Pembelajaran dan Kemahasiswaan.

2. Kopertis dalam mendistribusikan kuota kepada perguruan tinggi swasta diwilayahnya harus mempertimbangkan jumlah mahasiswa, prestasi dan ketaatan perguruan tinggi.

3. Perguruan tinggi dalam mengatur proposrsi kuota antara beasiswa dan bantuan biaya pendidikan harus bedasarkan data dan dijelaskan dalam laporan program. 
Berikut uraian kriteria dari kebijakan Kopertis Wilayah $\mathrm{X}$ dalam menentukan perguruan tinggi swasta penerima beasiswa PPA dan BBM di wilayahnya, yaitu:

1. Perguruan Tinggi Swasta (PTS) yang Taat Asas

PTS harus taat asas EPSBED, memenuhi syarat ketentuan dosen dan jumlah mahasiswa hingga kecukupan rasio dosen dan mahasiswa dalam setiap institusi.

2. Status Akreditasi Perguruan Tinggi/Program Studi

Penilaian atas kelayakan PTS mana yang mendapatkan kuota beasiswa diberikan kepada PTS dengan Akreditasi Program Studi A dan B.

3. Aktivitasi Perguruan Tinggi

Prinsip kerja AHP adalah penyederhanaan suatu persoalan kompleks yang tidak terstruktur dan dinamik menjadi bagian-bagiannya, serta menata dalam hierarki. Kemudian tingkat kepentingan setiap variabel diberi nilai numerik secara subjektif tentang arti penting variabel tersebut secara relative dibandingkan dengan varaibel yang lain. Dari berbagai pertimbangan tersebut kemudian dilakukan sintesa untuk menetapkan variabel yang memiliki prioritas tinggi dan berperan untuk mempengaruhi hasil pada sistem tersebut.

AHP merupakan suatu model pendukung keputusan yang dikembangkan oleh Dr. Thomas L. Saaty. Pada Gambar 1, secara grafis didefinisikan suatu representasi dari sebuah permasalahan yang kompleks dalam suatu struktur multilevel dimana level pertama adalah tujuan, yang diikuti level faktor, kriteria, sub kriteria, dan seterusnya ke bawah hingga level terakhir dari alternatif. Dalam menyelesaikan permasalahan dengan AHP ada beberapa prinsip yang harus dipahami, diantaranya adalah:

1. Membuat hierarki Sistem yang kompleks bisa diatasi dengan memecahnya menjadi elemen - elemen pendukung, menyusun elemen secara hierarki dan menggabungkannya atau mensintesisnya

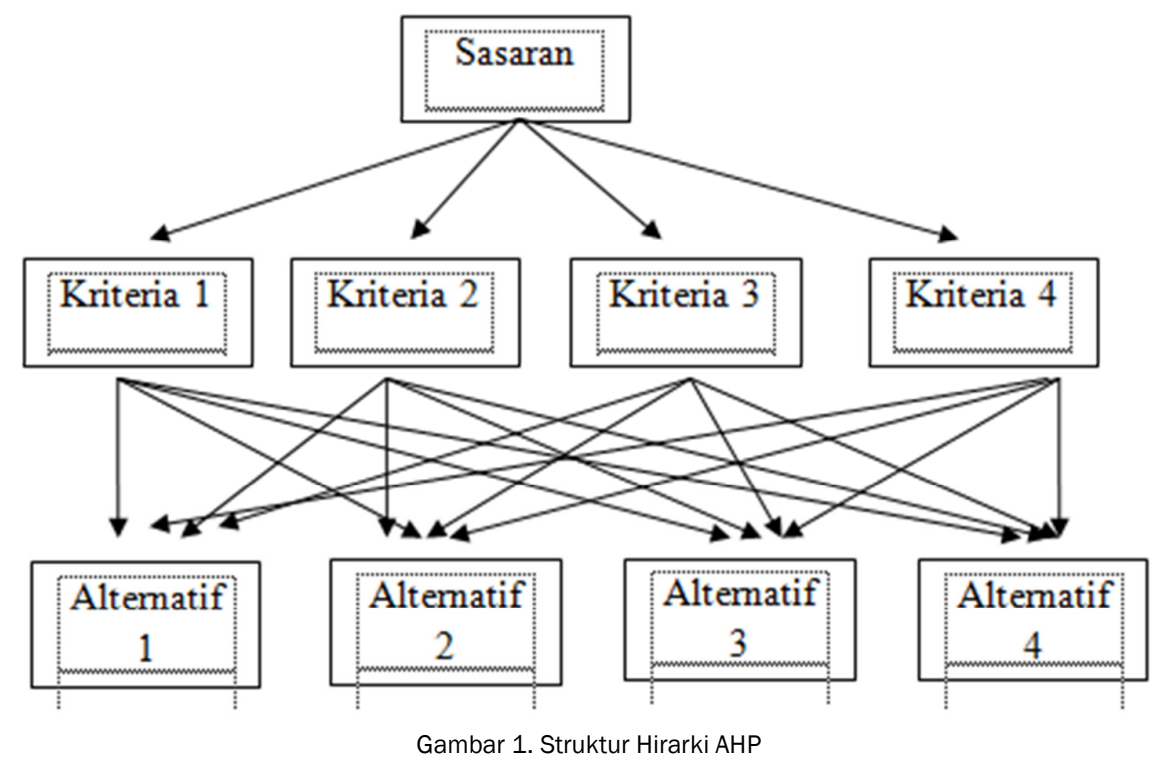

2. Penilaian kriteria dan alternatif

Kriteria dan alternatif dilakukan dengan perbandingan berpasangan. Menurut Saaty (1988), untuk berbagai persoalan skala 1 sampai 9 adalah skala terbaik untuk mengekspresikan pendapat.

3. Synthesis of priority (Menentukan prioritas)

Untuk setiap kriteria dan alternatif, perlu dilakukan prbandingan berpasangan (Pairwise Comparisons). Nilai-nilai perbandingan relatif dari seluruh alternatif kriteria bisa disesuaikan dengan judgement yang telah ditentukan untuk menghasilkan bobot dan prioritas. Bobot dan prioritas dihitung dengan memanipulasi matrix atau melalui penyelesaian persamaan matematika.

4. Logical Consistency (Konsistensi Logis)

Konsistensi memiliki dua makna. Pertama, objek-objek yang serupa bisa dikelompokkan sesuai dengan keseragaman dan relevansi. Kedua menyangkut tingkat hubungan antarobjek yang didasarkan pada kriteria tertentu. 
AHP memiliki banyak keunggulan dalam menjelaskan proses pengambilan keputusan, karena dapat digambarkan secara grafis, sehingga mudah dipahami oleh semua pihak yang terlibat dalam pengambilan keputusan. Selain itu AHP juga menguji konsistensi penilaian, bila terjadi penyimpangan yang terlalu jauh dari nilai konsistensi sempurna, maka hal ini menunjukkan bahwa penilaian perlu diperbaiki, atau hierarki distruktur ulang. Adapun langkah-langkah metode AHP adalah:

1. Menentukan jenis-jenis kriteria yang akan menjadi persyaratan calon PTS peneriama beasiswa yang mengikuti seleksi.

2. Menyusun kriteria-kriteria tersebut dalam bentuk matriks berpasangan.

3. Menjumlah matriks kolom.

4. Menghitung nilai elemen kolom kriteria dengan rumus masing-masing elemen kolom dibagi dengan jumlah matriks kolom.

5. Menghitung nilai prioritas kriteria dengan rumus menjumlah matriks baris hasil langkah ke 4 dan hasilnya 5 dibagi dengan jumlah kriteria.

6. Menentukan alternatif-alternatif yang akan menjadi pilihan.

7. Menyusun alternatif-alternatif yang telah ditentukan dalam bentuk matriks berpasangan untuk masing-masing kriteria. Sehingga akan ada sebanyak $n$ buah matriks, masing-masing matriksnya dijumlah per kolomnya.

8. Masing-masing matriks berpasangan antar alternatif sebanyak $n$ buah matriks, masing-masing matriksnya dijumlah per kolomnya.

9. Menghitung nilai prioritas alternatif masing-masing matriks berpasangan antar alternatif dengan rumus seperti langkah 4, dan langkah 5.

10. Menyusun matriks baris antara alternatif versus kriteria yang isinya hasil perhitungan proses langkah 7 , langkah 8 dan langkah 9.

11. Hasil akhirnya berupa prioritas global sebagai nilai yang digunakan oleh pengambil keputusan berdasarkan skor tertinggi.

Dalam penilaian kriteria dan alternatif menurut Saaty (1983), untuk berbagai persoalan, skala 1 sampai 9 adalah skala terbaik dalam mengekspresikan pendapat. Nilai dan definisi pendapat kualitatif dari skala perbandingan Saaty dapat dilihat pada Tabel 1 berikut:

\begin{tabular}{|c|l|}
\hline \multicolumn{1}{|c|}{ Nilai } & \multicolumn{1}{c}{ Tabel 1. Nilai Definisi Pendapat Kualitatif dari Skala Perbandingan } \\
\hline 1 & Kedua elemen sama pentingnya \\
\hline 3 & Elemen yang satu sedikit lebih penting dari pada elemen lainnya. \\
\hline 5 & Elemen yang satu lebih penting dari pada elemen lainnya. \\
\hline 7 & Satu elemen jelas lebih mutlak penting dari pada elemen lainnya. \\
\hline 9 & Satu elemen mutlak penting dari pada pertimbangan elemen lainya \\
\hline $2,4,6,8$ & Nilai-nilai antara dua nilai pertimbangan yang berdekatan \\
\hline Kebalikan & $\begin{array}{l}\text { Jika aktivitas } i \text { mendapat angka perbandingan dengan aktivitas } i, \text { maka } i \text { memiliki nilai } \\
\text { kebalikannya dibandingkan dengan } i\end{array}$ \\
\hline
\end{tabular}

\section{METODOLOGI PENELITIAN}

Metodologi yang digunakan dalam penelitian ini meliputi:

1. Studi Literatur

Pada tahap ini diadakan studi literatur tentang Sistem Penunjang Keputusan (SPK) dan Analitycal Hierarchy Process (AHP), pengumpulan data-data pendukung yang dibutuhkan.

2. Survey Data

Pada tahap ini dilakukan pencarian data tentang kriteria pengambilan keputusan penerimaan beasiswa PPA dan BBM bagi Perguruan Tinggi Swasta (PTS) di Kopertis Wilayah X.

3. Perancangan dan Pembuatan Sistem

Dari data yang didapatkan selanjutnya dilakukan analisa dan perancangan terhadap sistem penunjang keputusan yang akan dibuat dengan menggunakan Analytical Hierarchy Process (AHP).

4. Pengujian dan Implementasi

Pengujian dan implementasi dimaksudkan untuk sejauh mana sistem yang dibuat pada penelitian ini dapat berfungsi sesuai dengan proses sistem yang diharapkan. 


\section{HASIL DAN PEMBAHASAN}

Perhitungan pembobotan alternatif dilakukan dengan cara menyusun matriks berpasangan untuk alternatif-alternatif bagi setiap kriteria.

1. Contoh Pembobotan Alternatif untuk Kriteria Pertama (Ketaatan Asas Perguruan Tinggi Swasta)

Masukkan data nama-nama calon PTS dalam matriks berpasangan, sebagai contoh penulis memasukkan empat alternatif dalam penghitungan bobot alternatif ini yaitu Calon Penerima 1, Calon Penerima 2, Calon Penerima 3 dan Calon Penerima 4. Kemudian dilakukan perbandingan antar Calon Penerima yang dapat dilihat pada Tabel 2 berikut:

Tabel 2. Tabel Perbandingan Berpasangan Pembobotan Alternatif untuk Kriteria PTS yang Taat Asas

\begin{tabular}{|c|c|c|c|c|}
\hline Ketaatan Asas & Calon Penerima 1 & Calon Penerima 2 & Calon Penerima 3 & Calon Penerima 4 \\
\hline Calon Penerima 1 & $1 / 1=1,00$ & $2 / 1=2,00$ & $1 / 4=0,250$ & $2 / 1=2,00$ \\
\hline Calon Penerima 2 & $1 / 2=0,50$ & $1 / 1=1,00$ & $1 / 3=0,33$ & $4 / 1=4,00$ \\
\hline Calon Penerima 3 & $4 / 1=4,00$ & $3 / 1=3,00$ & $1 / 1=1,00$ & $4 / 1=4,00$ \\
\hline Calon Penerima 4 & $1 / 2=0,50$ & $1 / 2=0,50$ & $1 / 3=0,333$ & $1 / 1=1,00$ \\
\hline JUMLAH & 6,000 & 6,500 & 1,950 & 11,000 \\
\hline
\end{tabular}

Setelah menentukan nilai/bobot perbandingan berpasangan, maka masing-masing sel di atas dibagi dengan jumlah kolom masing-masing, contoh untuk mengisi kolom pertama (Calon Penerima 1, Calon Penerima 1) yaitu bobot Calon Penerima 1 = 1,00; jumlah Calon Penerima $1=6,000$ sehingga diperoleh hasil untuk kolom pertama (Calon Penerima 1, Calon Penerima 1) $=1 / 6=0,1666$ seperti yang ada di Tabel 3 (gunakan cara yang sama untuk mengisi kolom yang lain).

Tabel 3. Tabel hasil Perbandingan Berpasangan Pembobotan Alternatif untuk Kriteria PTS yang Taat Asas

\begin{tabular}{|c|c|c|c|c|c|}
\hline Ketaatan Asas & Calon Penerima 1 & Calon Penerima 2 & Calon Penerima 3 & Calon Penerima 4 & Jumlah \\
\hline Calon Penerima 1 & 0,1666 & 0,3076 & 0,1282 & 0,1818 & 0,7842 \\
\hline Calon Penerima 2 & 0,0833 & 0,1538 & 0,1692 & 0,3636 & 0,7699 \\
\hline Calon Penerima 3 & 0,6666 & 0,4615 & 0,5128 & 0,3636 & 2,0045 \\
\hline Calon Penerima 4 & 0,0833 & 0,0769 & 0,1707 & 0,0909 & 0,4218 \\
\hline
\end{tabular}

Setelah diketahui hasil jumlah tiap baris, maka hitung nilai prioritas alternatif untuk kriteria PTS yang taat asas dengan rumus jumlah baris dibagi dengan banyaknya alternatif (dalam penelitian ini ada 4 alternatif), sebagai contoh untuk mengisi kolom pertama (prioritas kriteria Calon Penerima 1) yaitu Jumlah baris Calon Penerima $1=0,7842$; banyak kriteria = 3 sehingga diperoleh hasil untuk kolom pertama (Prerioritas kriteria Calon Penerima 1$)=0,7842 / 3$ = 0,2614 seperti yang ada di Tabel 4 (gunakan cara yang sama untuk mengisi kolom yang lain).

Tabel 4. Tabel Hasil Prioritas Kriteria PTS Penerima Beasiswa PPA dan BBM Berdasarkan Ketaatan Asas PTS

\begin{tabular}{|l|c|c|}
\hline Ketaatan Asas & PRIORITAS KRITERIA & RANGKING \\
\hline Calon Penerima 1 & 0,2614 & II \\
\hline Calon Penerima 2 & 0,2566 & III \\
\hline Calon Penerima 3 & 0,6682 & I \\
\hline Calon Penerima 4 & 0,1406 & IV \\
\hline
\end{tabular}

2. Pembobotan alternative untuk kriteria berikutnya

Contoh pembobotan untuk kriteria berikutnya seperti status akreditasi program studi dan aktivitasi perguruan tinggi dapat dilakukan seperti cara di atas. Hasil perhitungan akhir diperoleh seperti Tabel 5 dan Tabel 6 berikut: 
Tabel 5. Tabel Hasil Prioritas Kriteria Penerima Beasiswa PPA dan BBM Berdasarkan Nilai Akreditasi Program Studi

\begin{tabular}{|c|c|c|}
\hline Aktivitasi & Prioritas Kriteria & Rangking \\
\hline Calon Penerima 1 & 0,4612 & II \\
\hline Calon Penerima 2 & 0,1655 & III \\
\hline Calon Penerima 3 & 0,6026 & I \\
\hline Calon Penerima 4 & 0,1041 & IV \\
\hline
\end{tabular}

Tabel 6. Tabel Hasil Prioritas Kriteria Penerima Beasiswa PPA dan BBM Berdasarkan Aktivitasi PTS

\begin{tabular}{|c|c|c|}
\hline Akreditasi & Prioritas Kriteria & Rangking \\
\hline Calon Penerima 1 & 0,2698 & III \\
\hline Calon Penerima 2 & 0,3465 & II \\
\hline Calon Penerima 3 & 0,2418 & IV \\
\hline Calon Penerima 4 & 0,4751 & I \\
\hline
\end{tabular}

Dari hasil pembobotan alternatif tiap kriteria di atas, maka dapat dibuat sebuah table prioritas global yang memuat semua data prioritas alternative berdasarkan kriterianya masing-masing seperti pada Tabel 7.

Tabel 7. Tabel Data Prioritas Global Penerima Beasiswa PPA dan BBM

\begin{tabular}{|c|c|c|c|c|}
\hline Global & Azaz Ketaatan & Aktivasi & Akrditasi & Total \\
\hline Calon Penerima 1 & 0,2614 & 0,4612 & 0,2698 & 0,9924 \\
\hline Calon Penerima 2 & 0,2566 & 0,1655 & 0,3465 & 0,7686 \\
\hline Calon Penerima 3 & 0,6682 & 0,6026 & 0,2418 & 1,5126 \\
\hline Calon Penerima 4 & 0,1406 & 0,1041 & 0,4751 & 0,7198 \\
\hline
\end{tabular}

Setelah diketahui hasil jumlah tiap baris, maka hitung nilai prioritas global dengan rumus jumlah baris dibagi dengan banyaknya alternatif (dalam penelitian ini ada 4 alternatif), sehingga diperoleh hasil seperti yang ada di Tabel 8.

Tabel 8. Tabel Hasil Prioritas Global Penerima Beasiswa PPA dan BBM

\begin{tabular}{|c|c|c|}
\hline Global & Prioritas Global & Rangking \\
\hline Calon Penerima 1 & 0,2481 & $\mathrm{II}$ \\
\hline Calon Penerima 2 & 0,1922 & $\mathrm{III}$ \\
\hline Calon Penerima 3 & 0,3782 & $\mathrm{I}$ \\
\hline Calon Penerima 4 & 0,1800 & $\mathrm{IV}$ \\
\hline
\end{tabular}

Dari hasil perhitungan prioritas global di atas, dihasilkan peringkat dari keempat calon penerima beasiswa PPA dan BBM yaitu Calon Penerima 3 menempati urutan pertama dengan urutan prioritas 0,3782, kemudian Calon Penerima 1 urutan kedua dengan nilai prioritas 0,2481, urutan ketiga adalah Calon Penerima 2 dengan nilai prioritas 0,1922 dan yang terakhir Calon Penerima 4 dengan nilai prioritas 0,1800.

\section{IMPLEMENTASI PERANGKAT LUNAK}

A. Input

Dalam sub menu input terdiri dari beberapa form entry data yang dibutuhkan oleh staf administrasi untuk pengolahan data beasiswa. Form input tersebut terdiri dari data provinsi, data perguruan tinggi swasta, kriteria, nilai kriteria, data user, data pegawai dan proses penilaian AHP yang dapat dilihat pada gambar berikut ini :

1. Menu Utama

Menu utama merupakan kerangka dasar dari beberapa sub program yang ada didalamnya sebagai tampilan utama dari program sistem pendukung keputusan penerimaan beasiswa ppa dan bbm pada perguruan tinggi swasta provinsi sumbar, riau, jambi dan kepri di kopertis wilayah x padang menggunakan metode ahp. Bagian 
utama dari menu sub menu utama menjalankan sub-sub dalam menu tersebut. Untuk lebih jelasnya dapat dillihat pada Gambar 2. berikut ini :

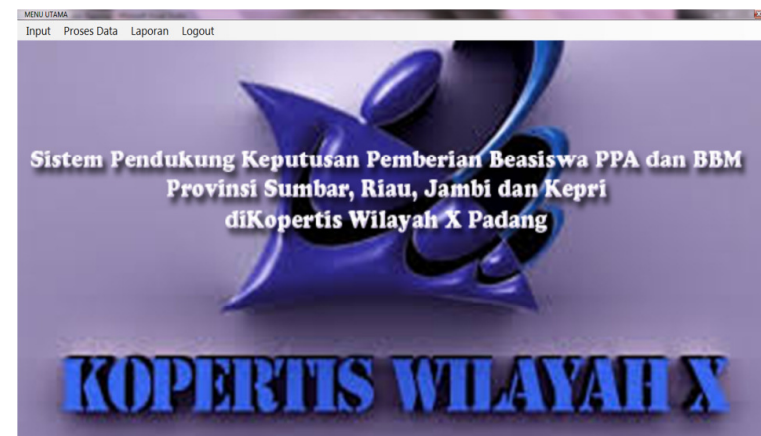

Gambar 2. Menu utama Sistem Pendukung Keputusan Pemberian beasiswa PPA dan BBM pada Perguruan Tinggi Swasta Provinsi Sumbar, Riau , Jambi dan Kepri

2. Menu Input

Input pada Sistem Pendukung Keputusan Penerimaan Beasiswa PPA dan BBM Pada Perguruan Tinggi Swasta Provinsi Sumbar, Riau , Jambi dan Kepri di Kopertis Wilayah X Padang terdiri dari 6 (enam) form seperti yang ditunjukkan pada gambar berikut:
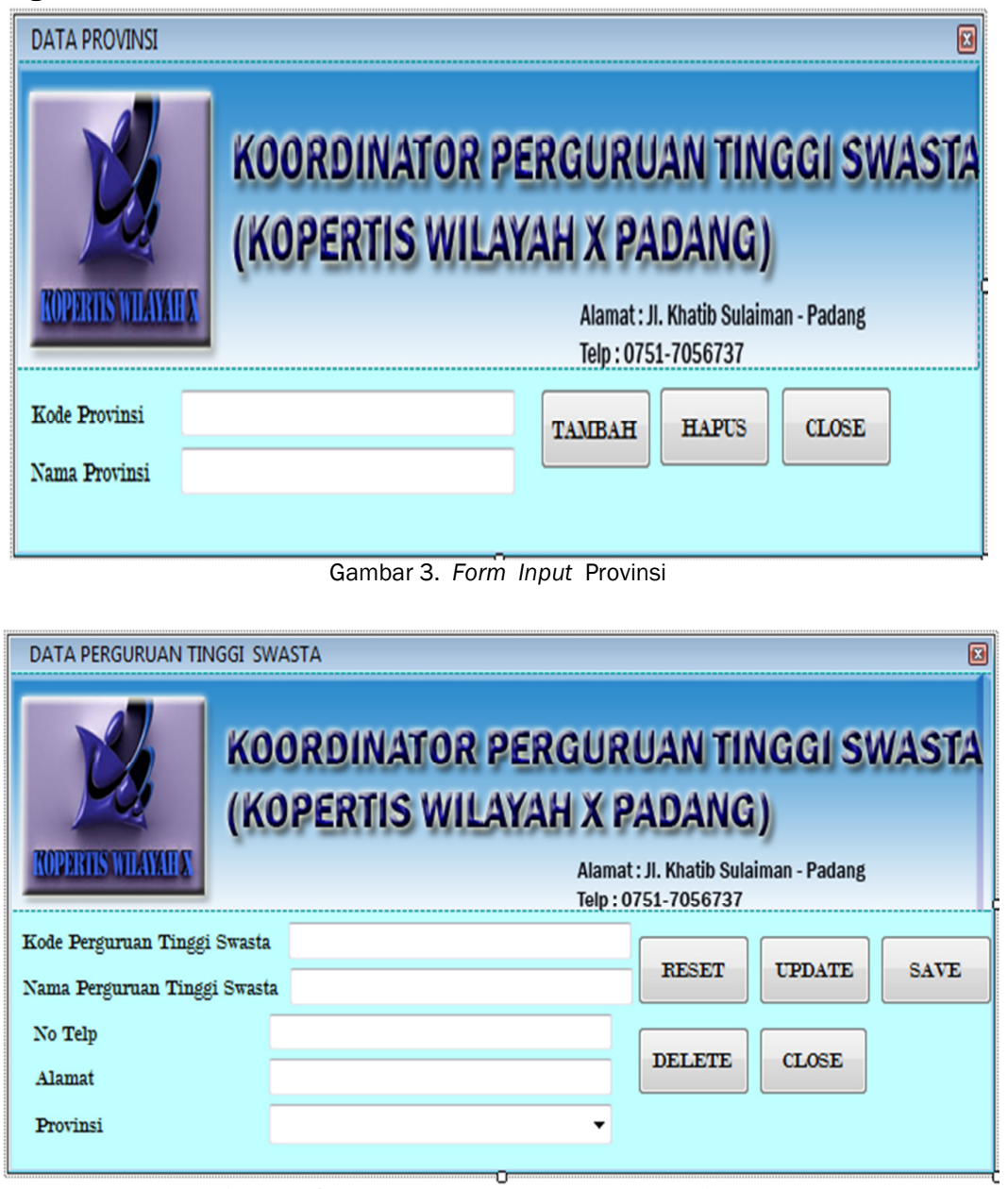

Gambar 4. Form Input Data Perguruan Tinggi Swasta 


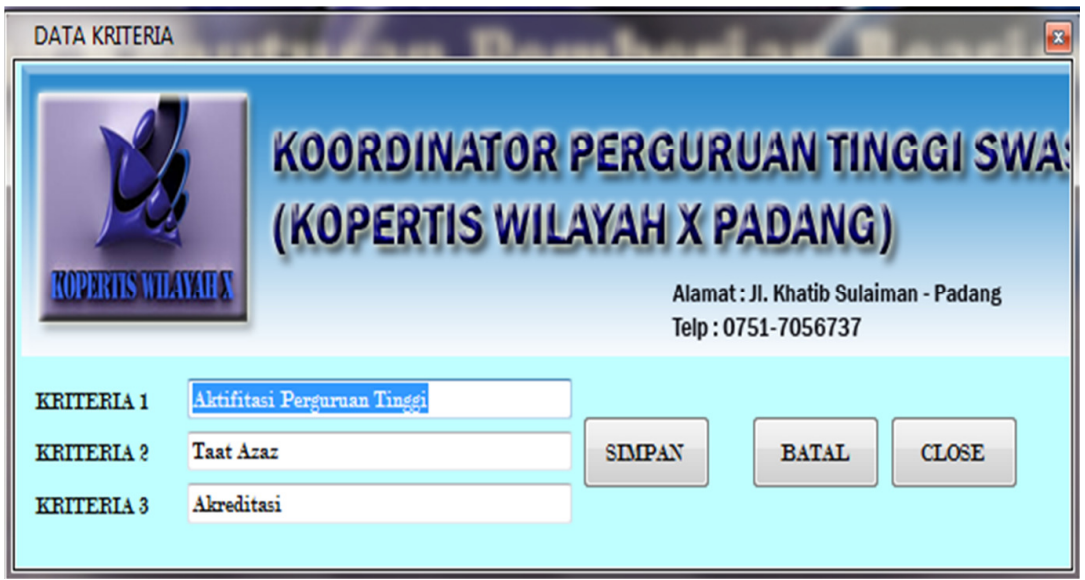

Gambar 5. Form Input Kriteria

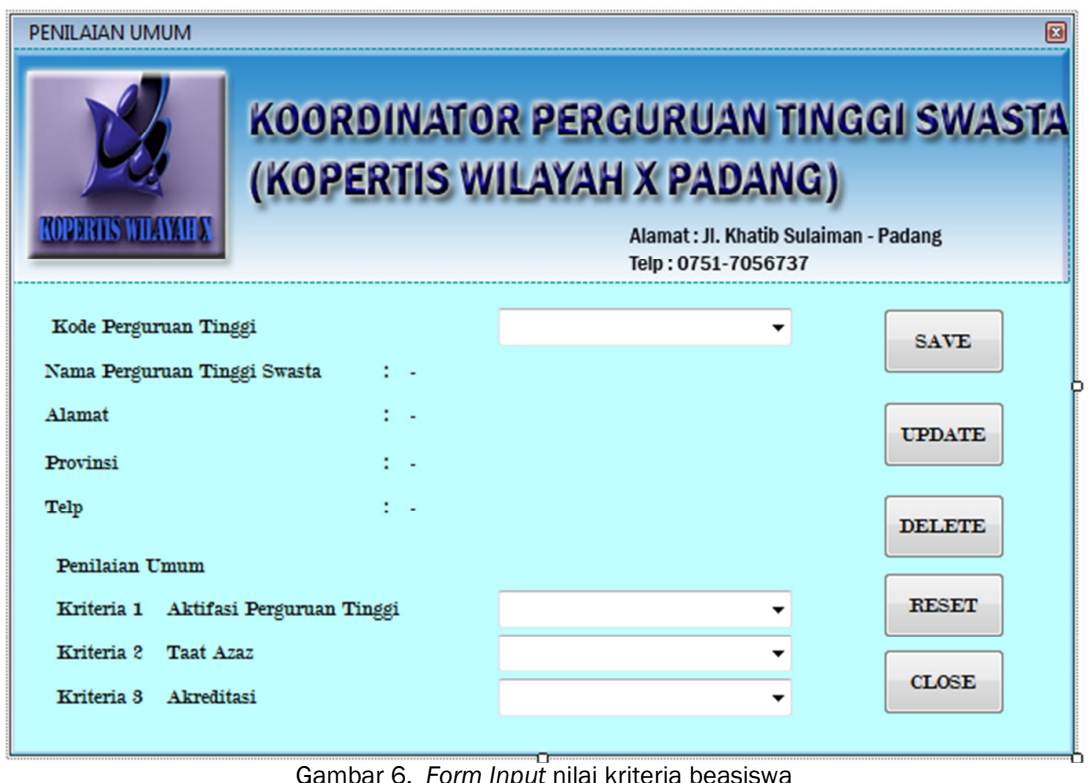

Gambar 6. Form Input nilai kriteria beasiswa

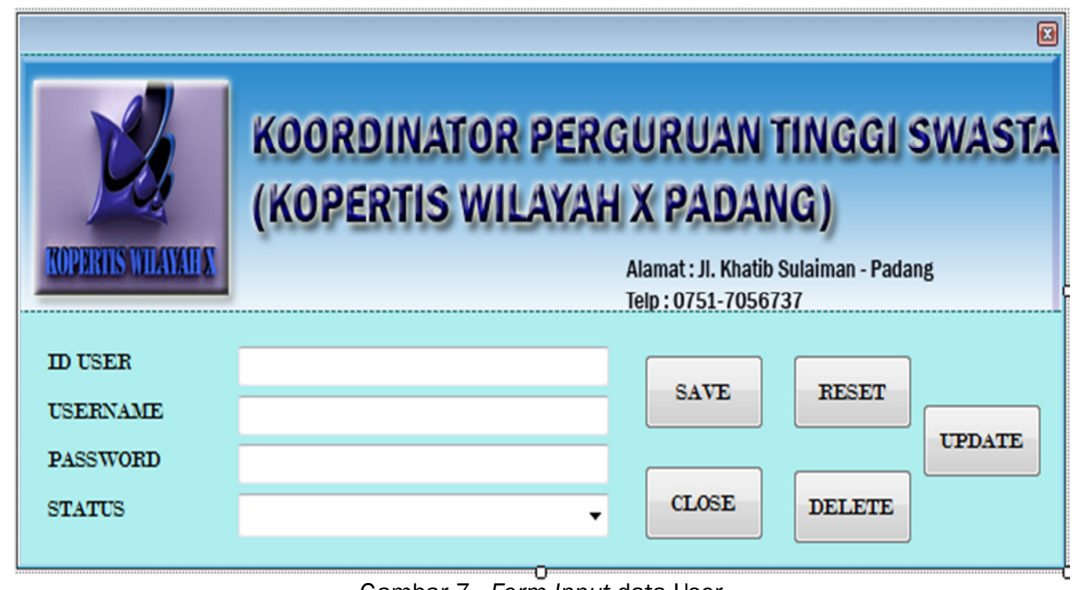

Gambar 7. Form Input data User 


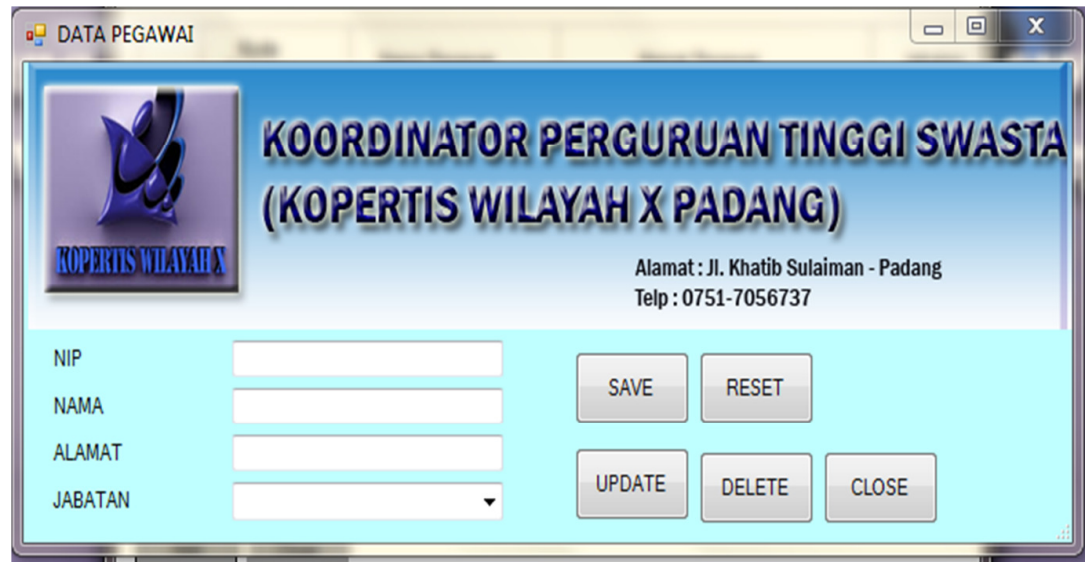

Gambar 8. Form Input data pegawai

3. Menu Proses

Menu proses Sistem Pendukung Keputusan Penerimaan Beasiswa PPA dan BBM Pada Perguruan Tinggi Swasta Provinsi Sumbar, Riau, Jambi dan Kepri di Kopertis Wilayah X Padang terdiri dari form proses penilaian Perguruan Tinggi Swasta. Dalam form proses Penilaian Perguruan Tinggi Swasta. user mengisi nilai masing-masing kriteria yang telah dikonversikan dalam penerimaan beasiswa PPA, untuk lebih jelasnya dapat dilihat pada Gambar 9, Gambar 10, Gambar 11, Gambar 12, Gambar 13.

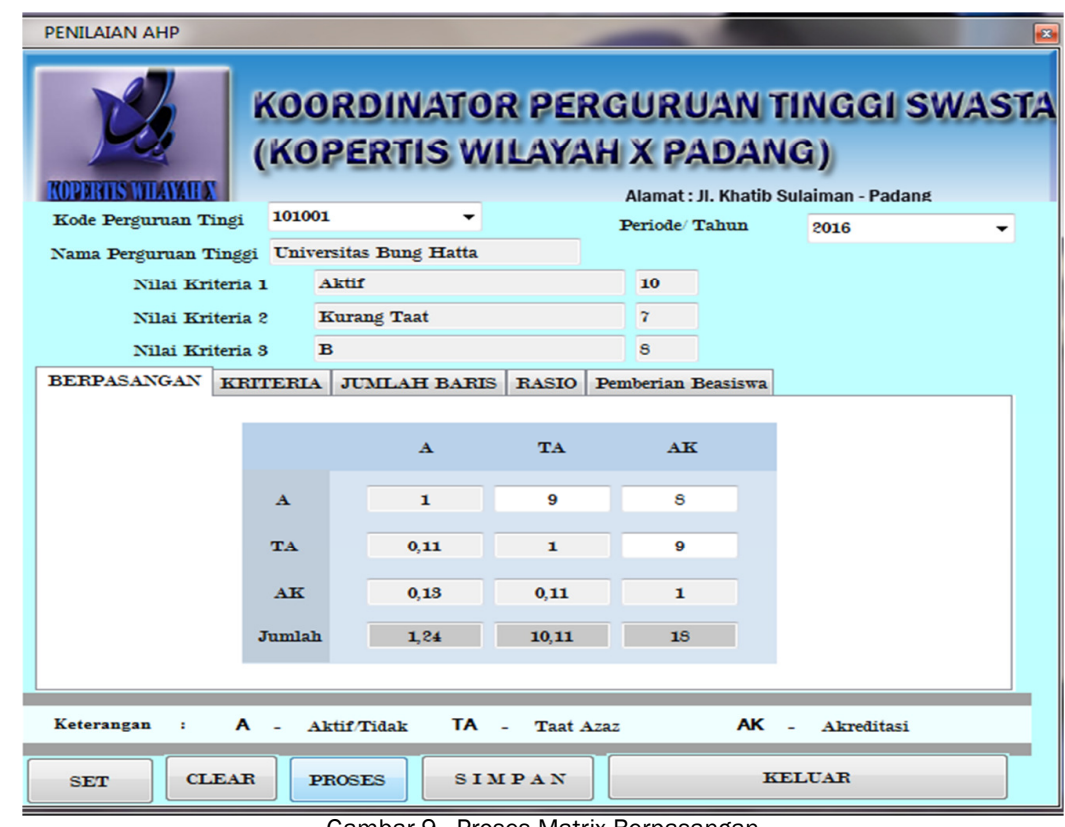

Gambar 9. Proses Matrix Berpasangan 


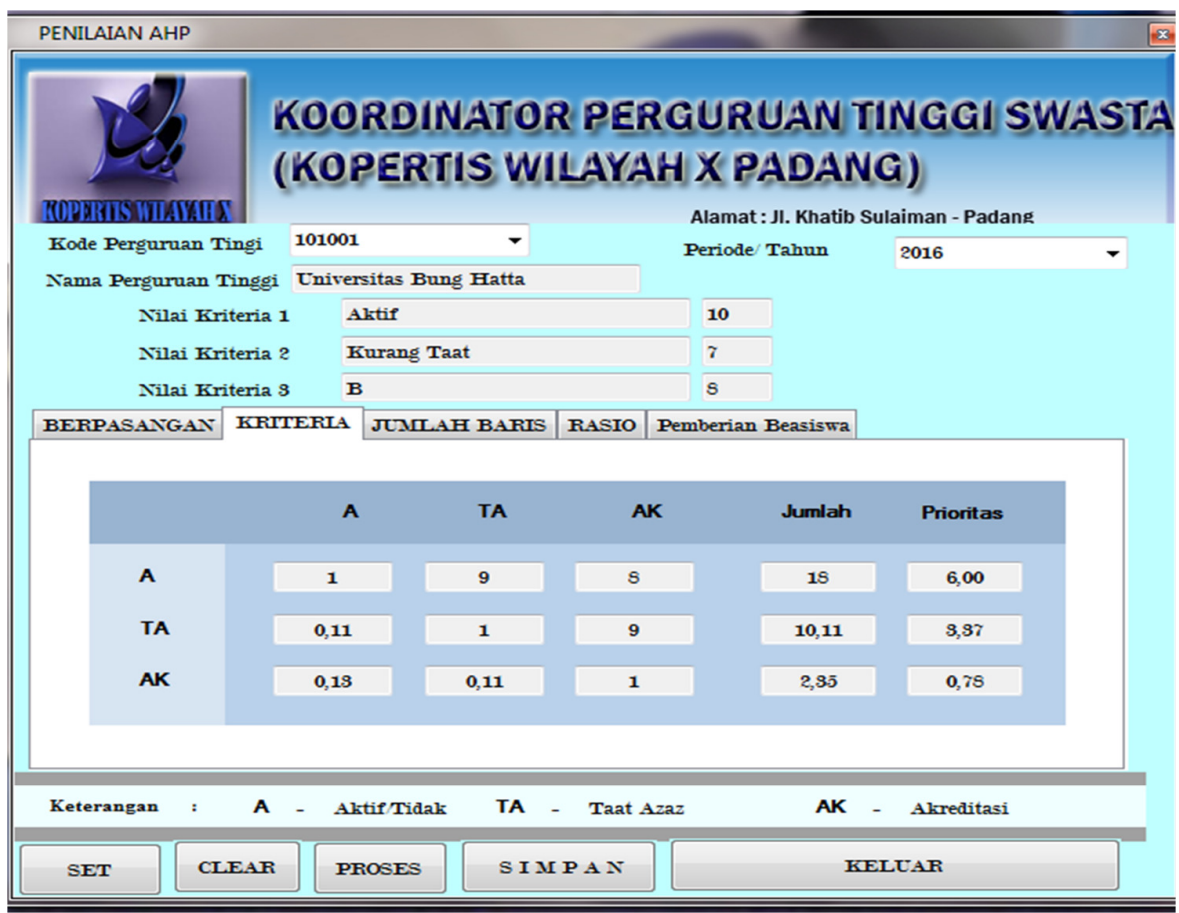

Gambar 10. Hasil Kuadrat Matrix Berpasangan

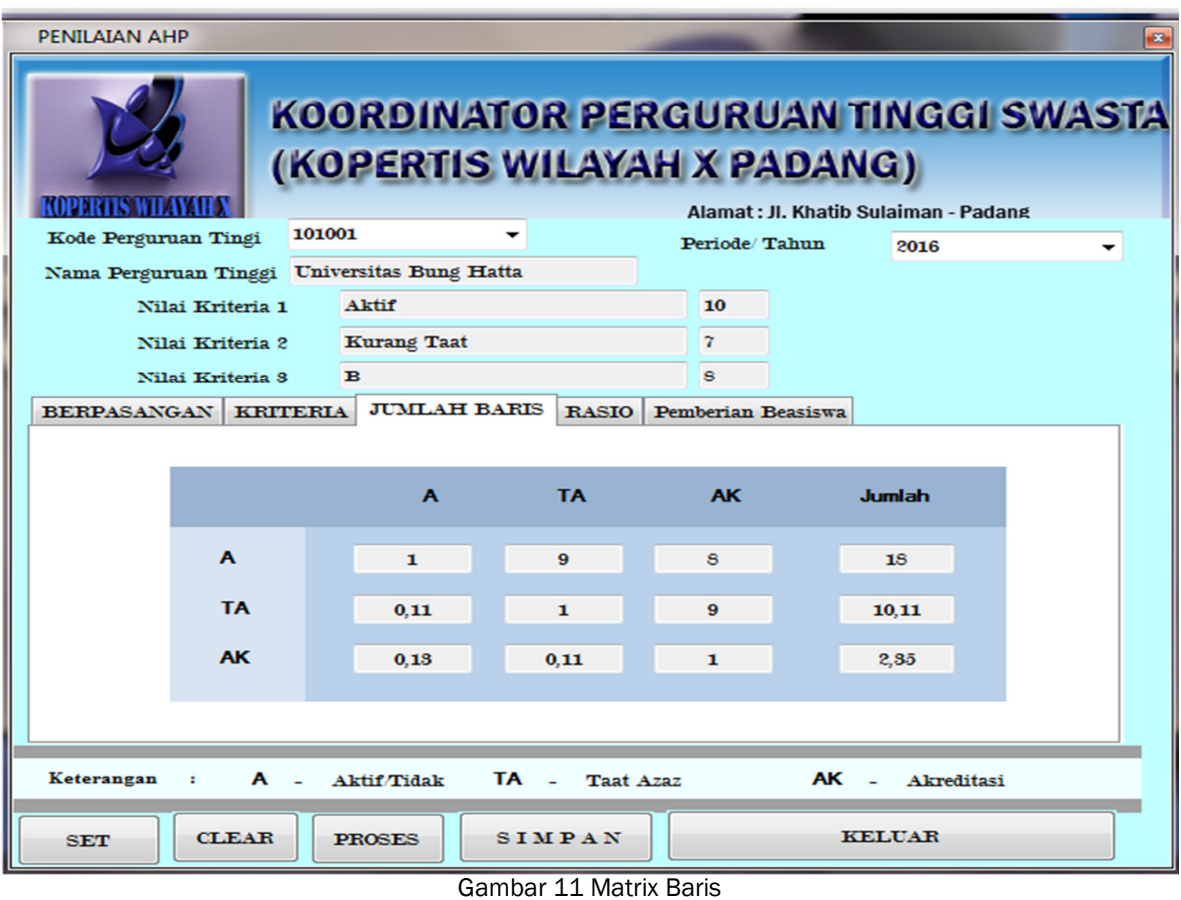




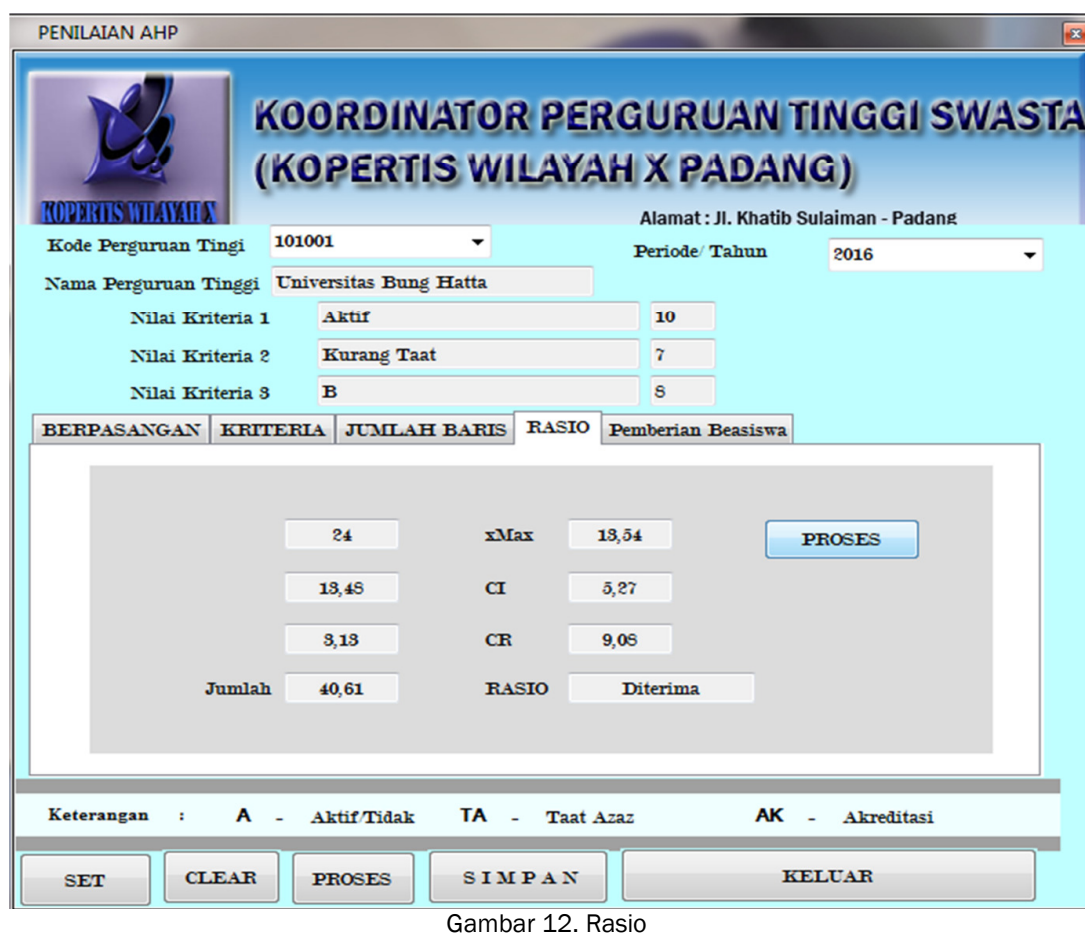

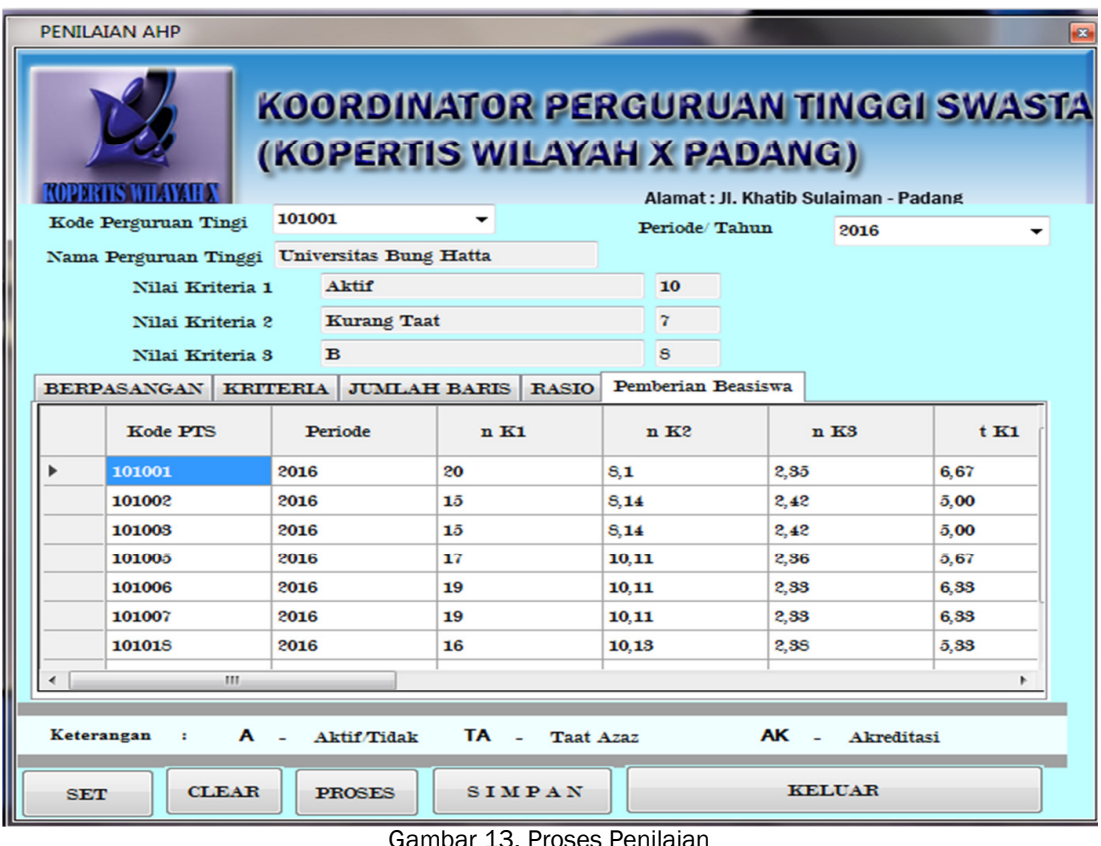

4. Output

Bentuk output berupa sub menu laporan yang terdiri dari beberapa modul yaitu Laporan Daftar Perguruan Tinggi Swata per Provinsi, Laporan Perguruan Tinggi Swasta Penerima Beasiswa PPA dan BBM, Laporan Pergururan Tinggi Swasta yang Menerima atau Tidak Menerima Beasiswa PPA dan BBM. Modul-modul laporan tersebut dapat dilihat pada gambar berikut ini : 


\begin{tabular}{|c|c|c|c|c|}
\hline RIITEK & $\frac{\mathrm{KOO}}{\mathrm{C}}$ & $\begin{array}{l}\text { TRIAN RISET. TEKN } \\
\text { I PERGURUAN TINC } \\
\text { PTS DI RUANG LINGF } \\
\text { tib Sulgims Tep. }(075\end{array}$ & 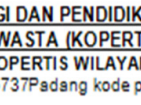 & $\begin{array}{l}\frac{N G G \mid}{L \text { LAYAHX X }} \\
\text { DANG } \\
\text { DA7 }\end{array}$ \\
\hline $\begin{array}{c}\text { Kode } \\
\text { PTS }\end{array}$ & Provinsi & Nama PTS & No Telp & Alamat \\
\hline 101001 & Sumgterg Bs st & $\begin{array}{l}\text { Universitas } \\
\text { Bung Hatta }\end{array}$ & +627517051678 & $\begin{array}{l}\text { Jl. Sumgterg, } \\
\text { Ulikksrang, Kote } \\
\text { Padang }\end{array}$ \\
\hline 101002 & Sumgters Bsrt & $\begin{array}{l}\text { Universitas } \\
\text { Muhsmmadiyg }\end{array}$ & $+62823-9043-19$ & $\begin{array}{l}\text { Pasie Nan Tigo. } \\
\text { Koto Tangh, Kots } \\
\text { Padsng }\end{array}$ \\
\hline 101003 & Sumgterg Bsst & $\begin{array}{l}\text { Universitss } \\
\text { Ekssgkt }\end{array}$ & +6275128859 & $\begin{array}{l}\text { Jl. Vetergn Dslam } \\
\text { No.26B, Psdsng } \\
\text { Pasir, Pgdang Ban }\end{array}$ \\
\hline 101005 & Sumsters Bsst & $\begin{array}{l}\text { Universitas } \\
\text { Tommnsisws }\end{array}$ & +6275140020 & $\begin{array}{l}\text { Jalan Taman Sisws } \\
\text { No.9. Padsng } \\
\text { Utsgs }\end{array}$ \\
\hline 101005 & Risu & $\begin{array}{l}\text { Universitas } \\
\text { Isism Risu }\end{array}$ & +6276172126 & $\begin{array}{l}\text { Jl. Kaharudn } \\
\text { Nasution No. } 113, \\
\text { Kotg Pekanbaru }\end{array}$ \\
\hline \multirow[t]{3}{*}{101007} & Rigu & $\begin{array}{l}\text { Universitas } \\
\text { Lancang }\end{array}$ & +6276153108 & $\begin{array}{l}\text { Jl. Yos Sudgrso } \\
\text { Km. 08, Kec. } \\
\text { Rumbai, Rigu } \\
\text { 28266. }\end{array}$ \\
\hline & & & & $\begin{array}{c}\text { Padsng:24/09/2016 } \\
\text { Padang }\end{array}$ \\
\hline & & & & $\begin{array}{l}\text { (Pof.Jhon Hendy.PhD) } \\
1958,10211987031001\end{array}$ \\
\hline
\end{tabular}

Gambar 14. Daftar Perguruan Tinggi Swasta Per Provinsi

KEMENTRIAN RISET,TEKNOLOGI DAN PENDIDIKAN TINGGI KOORDINASI PERGURUAN TINGGI SWASTA (KOPERTIS) WLLAYAH X jl. Khatib Sulaiman Telp. (0751) 7056737 PADANG Kode Pos . 25137 LAPORAN PERGURUAN TINGGI SWASTA YANG MENERIMA BEASISWA PPA DAN BBM

\begin{tabular}{|c|c|c|c|c|c|c|c|c|c|}
\hline Kode PTS & Nama PTS & Provinsi & N.Kriteria 1 & N.Kriteria 2 & N. Kitteria 3 & $x_{\max }$ & $\mathrm{Ci}$ & ar & Rasio \\
\hline 101001 & Universitas Bunghtata & Sumatera Barat & Altf & Kurang Tadt & B & 12,68 & 4,84 & 8,34 & Diterima \\
\hline 101003 & Universitas Ekasath & Sumatera Barat & Proses & Taat & A & 13,11 & 5,06 & 8,72 & Diterima \\
\hline 101005 & Universitias Tamansisva & Sumatera Barat & Aktf & Kurang Tatt & A & 13,11 & 5,06 & 8,72 & Diterima \\
\hline 101006 & Universitas Islam Riau & Riau & Altaft & Kurang Tast & A & 13,11 & 5,06 & 8,72 & Diterima \\
\hline 101007 & Universitas Lancang Kuning & Riau & Aktf & Tast & A & 13,97 & 5,49 & 9,46 & Diterima \\
\hline
\end{tabular}

Padang,24/09/2016

Padang

(Prof.Jhon Hendy, Ph.D)

1958.1021. 1987031001

Gambar 15. Laporan Perguruan Tinggi Swasta yang menerima beasiswa PPA dan BBM 


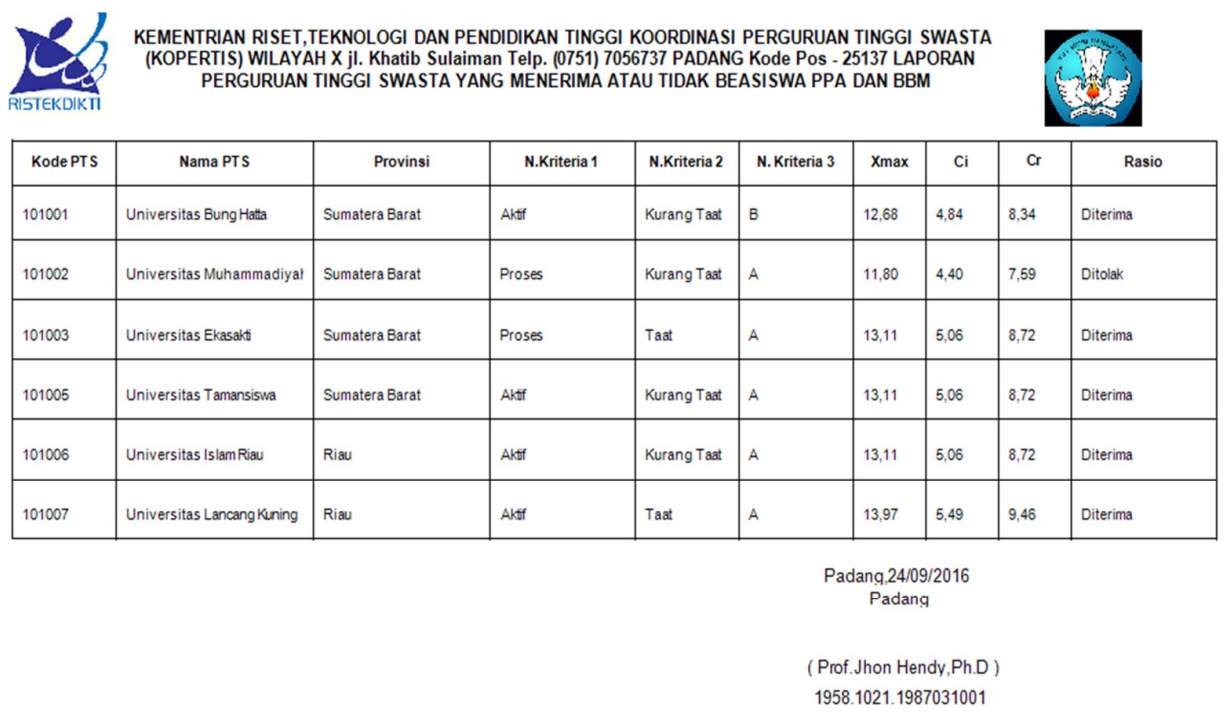

Gambar 16. Laporan Perguruan Tinggi Swasta yang menerima atau tidak beasiswa PPA dan BBM

\section{PENGUJIAN}

Tahap pengujian merupakan tahap terakhir dalam menggambarkan sistem yaitu meletakkan sistem supaya siap dioperasikan. Pengujian berguna untuk memudahkan penerapan sistem yang disiapkan agar proses input data sampai pada penyajian informasi sesuai dengan prosedur yang telah direncanakan. Sebelum program diterapkan, program harus bebas terlebih dahulu dari kesalahan-kesalahan yang mungkin terjadi. Program diuji tiap-tiap modul dan dilanjutkan dengan pengujian ke semua modul yang telah dirangkai. Kesalahan yang mungkin terjadi dapat diklasifkasikan dalam tiga bentuk yaitu sebagai berikut :

1. Kesalahan bahasa (language errors) atau disebut juga dengan kesalahan penulisan (syntax errors), adalah kesalahan dalam menulis penulisan source program yang tidak sesuai dengan yang sudah disyaratkan.

2. Kesalahan waktu proses (runtime errors), adalah kesalahan yang terjadi sewaktu program dijalankan. Kesalahan ini akan menyebabkan proses program terhenti sebelum selesai pada saatnya karena compiler menemukan kondisikondisi yang belum terpenuhi yang tidak terbiasa dikerjakan.

3. Kesalahan logika (logical errors), adalah kesalahan dari logika program yang dibuat.

Setelah bebas dari kesalahan dilanjutkan dengan pengujian sistem. Tujuan utama dari pengujian sistem adalah untuk memastikan bahwa elemen-elemen atau komponen-komponen dari sistem telah berfungsi sesuai dengan yang diharapkan. Pengujian perlu dilakukan untuk mencari kesalahan-kesalahan yang mungkin terjadi.

\section{KESIMPULAN}

1. Dalam proses pengambilan keputusan untuk seleksi penerima beasiswa PPA dan BBM di lingkungan Kopertis Wilayah $\mathrm{X}$ melalui 3 tahap yaitu tahap perumusan masalah, tahap pembobotan alternatif dan tahap penentuan ranking.

2. Adapaun kriteria-kriteria yang diambil dalam aplikasi ini mengacu pada:

a. Pedoman Umum Beasiswa Bantuan Biaya Pendidikan Peningkatan Prestasi Akademik Tahun 2015 diperoleh informasi tentang kuota penerima beasiswa PPA dan BBM, yaitu:

1) Kuota calon penerima pada setiap perguruan tinggi negeri dan kopertis ditentukan oleh Direktorat Jenderal Pembelajaran dan Kemahasiswaan.

2) Kopertis dalam mendistribusikan kuota kepada perguruan tinggi swasta diwilayahnya harus mempertimbangkan jumlah mahasiswa, prestasi dan ketaatan perguruan tinggi.

3) Perguruan tinggi dalam mengatur proposrsi kuota antara beasiswa dan bantuan biaya pendidikan harus bedasarkan data dan dijelaskan dalam laporan program.

b. Kebijakan Kopertis Wilayah $\mathrm{X}$ dalam menentukan perguruan tinggi swasta penerima beasiswa PPA dan BBM di wilayahnya, yaitu: 
1) Perguruan Tinggi Swasta (PTS) yang Taat Asas

PTS harus taat asas EPSBED, memenuhi syarat ketentuan dosen dan jumlah mahasiswa hingga kecukupan rasio dosen dan mahasiswa dalam setiap institusi.

2) Status Akreditasi Perguruan Tinggi/Program Studi

Penilaian atas kelayakan PTS mana yang mendapatkan kuota beasiswa diberikan kepada PTS dengan Akreditasi Program Studi A dan B.

3) Aktivitasi Perguruan Tinggi

3. Sistem Penunjang Keputusan yang dibuat dengan metode AHP melakukan perhitungan secara otomatis ketika user menginputkan nilai dan bobot, sehingga dapat mengurangi masalah dalam pengambilan keputusan dalam penentuan PTS yang berhak menerima kuota beasiswa PPA dan BBM.

4. Hasil akhir dari aplikasi ini berupa proses pemilihan yang berupa laporan yang memuat semua komponen yang berperan dalam proses pemilihan.

\section{REFERENSI}

[1] Prasetyo, Tri Ferga, Chandra Kusumah. Sistem Penunjang Keputusan Seleksi Mahasiswa Berprestasi Menggunakan Metode AHP (Studi Kasus: Universitas Majalengka), diterbitkan di Jurnal J-Ensitec: Volume 2 No.01 November 2015

[2] Fitriyani. Penerapan AHP sebagai Model Sistem Pendukung Keputusan Rumah Bersalin contoh Kasus kota Pangkal Pinang, diterbitkan di JSM Mikrosil pada Volume 13(2) Oktober 2012. ISSN.1412-0100.

[3] Jogiyanto. Analisis dan Desain Sistem Informasi. Yogyakarta: Andi Offset. 2005

[4] Kusrini. Konsep dan Aplikasi Sistem Pendukung Keputusan. Yogyakarta: C.V Andi Offset. 2007.

[5] Magdalena,Hilyah. Sistem Keputusan untuk Menentukan Mahasiswa Lulusan Terbaik di Perguruan Tinggi Swasta Studi Kasus STMIK ATMA LUHUR Pangkal Pinang) diterbitkan di Seminar Nasional Teknologi Informasi dan Komunikasi Maret 2012.ISSN.2089-9815

[6] Makassau, Kasman. Penggunaan Metode Analytic Hierarchy Process (AHP) Dalam Penentuan Prioritas Program Kesehatan (Studi Kasus Program Promosi Kesehatan), diterbitkan di Jurnal J@TI Undip, Vol VII, No 2, Mei 2012.

[7] Nugroho,Andi. Perancangan dan Implementasi Sistem Basis Data. Yogyakarta : CV. Andi Offset. 2011.

[8] Pakereng, Inneke, Teguh Wahyono. Sistem Basis Data Konsep dan Pendekatan Praktikum. Yogykarta : Penerbit Graha IImu. 2004 